ROCZNIKI HUMANISTYCZNE

Volume 67, issue 2 - 2019

SELECTED PAPERS IN ENGLISH

DOI: http://dx.doi.org/10.18290/rh.2019.68.2-5en

JAROSŁAW RABIŃSKI

\title{
THE IMAGE OF THE UNITED STATES OF AMERICA IN THE POLISH NEWSREELS (PKF) 1948-1953
}

\section{INITIAL REMARKS}

The relations between the Union of Soviet Socialist Republics and the United States of America and both these sides' allies, formed in the last months of World War II $^{1}$ and influencing the next decades, were characterized by acute tension, and although its intensity varied, it always had an antagonistic character. It was were given the name "Cold War", albeit the term - indicating the character of the conflict that is different from the "hot" armed confrontation - is a little misleading. In principle, its meaning is adequate for the military dimension, since, despite some cases of direct armed combat between American and Soviet soldiers, an armed clash between the USA and the USSR never happened. However, the war on other planes economic, ideological, and also propaganda, as a result of the latter - was decidedly not a cold war. The subject of the present discussion concerns this last aspect.

The long, 46-year period of the Cold War rivalry favors introducing some caesuras that could make it possible to describe the dynamics of the process-

Dr. hab. JAROSŁAW RABIŃSKI - John Paul II Catholic University of Lublin, Institute of History, Department of Modern History; address for correspondence: Al. Racławickie 14, 20-950 Lublin; e-mail: jaroslaw.rabinski@kul.lublin.pl.

The Polish version of the article was published in Roczniki Humanistyczne 59 (2011), issue 2.

${ }^{1}$ Włodzimierz MALENDOwSKI, “Zimna wojna. Rywalizacja radziecko-amerykańska w systemie bipolarnym. Problemy periodyzacji i rekonstrukcji najważniejszych zdarzeń [The Cold War. The Soviet-American Rivalry in a Bi-polar System: The Problems of the Periodization and Reconstruction of the Most Important Events]." In Zimna wojna (1946-1989) i jej konsekwencje dla tadu międzynarodowego [The Cold War (1946-1989) and Its Consequences For the International Order], ed. Bogdan Koszel and Sebastian Wojciechowski (Poznań: Instytut Zachodni. Wyższa Szkoła Nauk Humanistycznych i Dziennikarstwa, 2007), 10. 
es that went on during that time and to analyze the features that were characteristic of each of these sub-periods. One of this types of suggestions is Włodzimierz Malendowski’s periodization. He divides the period of the Cold War into seven phases:

1. 1945-1947 (the breakdown of the Grand Alliance and the start of the confrontation);

2. 1948-1953 (growing confrontation);

3. 1954-1962 (fluctuating antagonism);

4. 1963-1969 (formation of the reasons for détente);

5. 1970-1979 (détente);

6. 1980-1985 (the second Cold War);

7. 1986-1991 (the final phase of the Cold War).

In the present discussion the image of the United States of America in Polish Newsreel in the second of the periods mentioned, defined by Malendowski as the "growing confrontation", or indeed "the zenith of the cold war," 3 will be analyzed. It was a time full of events that had a key significance for shaping the international scene after the war, such as, among others, the seizing of power in Czechoslovakia and in China by the Communists, the first Berlin crisis and the Korean War. It is also the final stage of Joseph Stalin's absolute power in the USSR, which influenced both the shape of international politics and the Soviet directives concerning the propaganda image of the USA followed in the other countries of the "people's democracy", including Poland. Hence, it is a period filled with facts that were fundamentally important and were bound to exert influence on the way the main antagonist of the Communist bloc was presented in propaganda. Moreover, with respect to post-war Poland's inner history, treating the years 1948-1953 as a separate period is valid as they were the time of the "leap into Stalinism" characterized by the full implementation of Soviet totalitarian patterns in all spheres of political life. ${ }^{4}$

These accepted caesuras are also important because of the history of Polish Newsreel (PKF) whose materials will be for us the source of material

\footnotetext{
${ }^{2}$ Ibid., p. 17.

${ }^{3}$ Ibid., p. 20; IDEM, Zimna wojna. Sprzeczności, konflikty i punkty kulminacyjne w radzieckoamerykańskiej rywalizacji [The Cold War. The Contradictions: Conflicts and Culminating Points in the Soviet-American Rivalry] (Poznań: Wydawnictwo Naukowe Instytutu Nauk Politycznych i Dziennikarstwa UAM, 1994), 33.

${ }^{4}$ Cf. Maria Hirszowicz, Pulapki zaangażowania. Intelektualiści w stużbie komunizmu [The Traps of Involvement: Intellectuals in the Service of Communism] (Warszawa: Scholar, 2001), $103-138$.
} 
for analyzing the propaganda image of the USA in Communist Poland. The editorial staff of the PKF was formed in 1944 from a circle of people who were members of the so-called Polish Army Film Unit "Czołówka", a group of film-makers directed by Aleksander Ford that was attached to the $1^{\text {st }}$ Tadeusz Kościuszko Infantry Division. On the $15^{\text {th }}$ of November 1944 "Czołówka" was transformed into the Polish Army Film Studio, subordinated to the Ministry of Information and Propaganda of the Communist Polish Committee of National Liberation and, at the same time, to the Chief Political-Educational Commandment of the $1^{\text {st }}$ Army of the Polish Armed Forces. Several days later - on the $1^{\text {st }}$ of December 1944 - the PKF was established; initially, it was run by Jerzy Bossak, an outstanding documentary filmmaker. In the original staff of the PKF there were representatives of four circles: former members of the Artistic Film Lovers' Association "Start" (apart from Bossak, they were Ludwik Perski, Stanisław Wohl and Władysław Forbert); a group of young film journalists (among others Stanisław Szwedo, Antoni Nowosielski and Henryk Makarewicz); film-makers from the interwar period and those who had worked in the underground (among them Wacław Kaźmierczak, Antoni Wawrzyniak, Eugeniusz Haneman and Ryszard Szope). It is characteristic of the time that the fourth group consisted of film-makers connected with the Soviet "Sojuzkronika": Ludmiła Niekrasowa and Eugeniusz Jefimow, who supervised the acceptance of the model of Soviet propaganda by Polish film-makers. ${ }^{5}$

The year 1949 brought about three significant events for the PKF. Firstly, in the office of the editor-in-chief of the 'Kronika' Bossak was substituted by Olga Borzechowa who performed this function for several months, and

\footnotetext{
${ }^{5}$ Marek CIEŚLIŃSki, Piękniej niż w życiu. Polska Kronika Filmowa 1944-1994 [More Beautiful Than Life: Polish Newsreel 1944-1994] (Warszawa: Trio, 2006), 31-33; Janusz UrbaniaK, “O sposobie realizowania 'Polskiej Kroniki Filmowej' w latach czterdziestych [On the Way 'Polish Newsreel' Was Edited in the Nineteen-Forties].” In Estetyka i struktura dzieta filmowego [The Esthetics and Structure of the Film], ed. Jan Trzynadlowski (Wrocław: Wydawnictwo Uniwersytetu Wrocławskiego, 1987), 204-205; IDEM, “'Polska Kronika Filmowa,' 'zimna wojna' i świat. O zmienności ekranowego obrazu ['Polish Newsreel,' the Cold War and the World: On the Changeability of the Screen Picture]," In Film: obraz - język - wyobraźnia - idea [Film: Picture - Language - Imagination - Idea], ed. Jan Trzynadlowski (Wrocław: Wydawnictwo Uniwersytetu Wrocławskiego, 1994), 214-216. The subject of Polish cinematography till 1949, taking into consideration the history of documentary film in the context of political reality of that time is discussed in the following works: Alina MADEJ, Kino. Władza. Publiczność. Kinematografia polska w latach 1944-1949 [The Cinema. The Authorities. The Audience: Polish Cinematography in the Years 1944-1949]. Bielsko-Biała: Prasa Beskidzka, 2002, and Joanna LEMANN- ZAJIČEK, Kino i polityka. Polski film dokumentalny 1945-1949 [The Cinema and Politics: Polish Documentary Films 1945-1949]. Łódź: PWSFTviT, 2003.
} 
then by Helena Lemańska who held the office till June 1967. The latter was responsible for the shape of the PKF for most of the time that is the subject of the present study. Secondly, in the middle of 1949 the editorial office was moved from Łódź to the Documentary Film Studio in Warsaw. And thirdly, on 19-22 of November 1949 a Congress of Film-Makers took place in Wisła, and during the congress a directive was accepted saying that Polish films were to be made in the spirit of Socialist Realism. All these facts indicate that the authorities tried to subordinate the PKF to the propaganda machine operated by the administration, both in the ideological and organizational sense. ${ }^{6}$ In the first years of the Polish People's Republic the PKF was one of the most important propaganda tools and, according to Janusz Urbaniak, indeed "the most powerful propaganda tool in the first years after the war". ${ }^{7}$ He estimates that in the forties the audience for each newsreel film by the PKF reached 4-5 million viewers, and fell to two million by 1954 . These numbers are impressive, especially compared to the total number of cinema goers in Poland estimated at 117 million in 1949 (which gives 2.4 million a week on the average). They reflect the great social need of an information film magazine which was screened not only before all film shows, but also during special shows, as part of mobile cinema shows, educational shows and so-called "current events".

The mass participation of Polish society in the PKF shows may be explained by several factors: in those times the newsreel played the role of the basic transmitter of information that was easier to access than the printed media and predominated over them by means of a more attractive form; people demonstrated a natural willingness to "soak up" information from their country and the world after a period of restrictions on access to them in the conditions of war and occupation; in the first years after the war the propaganda in the PKF was considerably more restrained (especially in comparison to the late forties and the first half of the fifties), which to a certain degree made it possible to maintain the PKF's role as a source of information, including relatively objective attempts at showing the special character of the Western world. ${ }^{8}$

${ }^{6}$ Marek CIEŚLIŃSKI, "Polska Kronika Filmowa 1945-1955. W kleszczach urzędniczych decyzji [Polish Newsreel 1945-1955: In the Grip of the Clerks' Decisions]." In Realizm socjalistyczny $w$ Polsce z perspektywy 50 lat [Socialist Realism in Poland from the Perspective of 50 Years], ed. Stefan Zabierowski (Katowice: Wydawnictwo UŚ, 2001), 244-247; URBAnIAK, "O sposobie realizowania „Polskiej Kroniki Filmowej” w latach czterdziestych,” 208-210.

${ }^{7}$ Urbaniak, “ 'Polska Kronika Filmowa,' 'zimna wojna' i świat”, 217.

${ }^{8}$ Ibid., 224-231. 
Polska Kronika Filmowa had the form of a weekly documentary film magazine about 10 minutes long dedicated to topical political-social events. Apart from this, special issues of Kronika were also made - they were devoted to one subject or field of human activity (army, sports, art), and some of them were even made into a series consisting of several parts that were devoted to one particular issue. Such special issues of the PKF could be as twice as long as a normal one. ${ }^{9}$

It is not obvious how the PKF should be classified according to its sources: is it included in the category of documentary film ${ }^{10}$ or treated as a separate form of historical film source ${ }^{11}$ The characteristic feature of the newsreel is its construction - it is a set of short documentary films arranged in a proper sequence giving it a peculiar dramatic effect, with the fundamental role, besides the footage, of the commentary explaining and interpreting the film being shown.

The commentary, apart from the film, was the crucial element of the PKF. Even casual participation in the screening of the newsreel shows that both the author of the commentary (it was written by, among others, Karol Małcużyński, Ludwik Perski and Jerzy Bossak, hiding under the pseudonym Jerzy Szelubski) and the narrator reading it (in a decided majority of the PKF reels in the period being discussed it was Andrzej Lapicki, the actor) were intellectually and emotionally involved in the created work. ${ }^{12}$ The language of the commentary shows the character of the PKF - its informative or persuasive tinge. Both the commentary and the proper vertical and horizontal editing of the presented footage were a perfect opportunity to form the desired propaganda effect. The choice and sequence of particular scenes and frames guided the spectator in the direction of "the only proper" interpretation of the footage watched. Often party and state slogans that were omnipresent in the public space in that time were fitted in and, in this way, the number of their recipients was multiplied. The authors of the PKF used archive material, and often combined it alternately archival and contemporary

\footnotetext{
${ }^{9}$ CIESLIŃKI, "Polska Kronika Filmowa 1945-1955," 255-256; IDEM, Piękniej niż w życiu, 41, 68-69, 167-172.

${ }^{10}$ Maciej SZCZUROwSKI, "Dokument filmowy i telewizyjny. Określenie problematyki badawczej, [Film and TV Documentaries: Defining the Research Issues]." In Dokument filmowy i telewizyjny [Film and TV Documentaries], ed. Maciej Szczurowski (Torun: Wydawnictwo Adam Marszałek, 2004), 29-31.

${ }^{11}$ Helena Karczowa, "Reportaż filmowy i kronika jako źródło historyczne [The Film Documentary and the Newsreel as a Historical Source]." Studia Źródłoznawcze 16 (1971): 26.

${ }^{12}$ CIEŚliński, Piękniej niż w życiu , 63-64; IDEM, "Polska Kronika Filmowa 1945-1955," 253; UrbaniaK, “'Polska Kronika Filmowa,' 'zima wojna' i świat,” 231.
} 
takes, which allowed the construing of parallels that were comprehensible for the viewer. Both in the commentary and in the editing process the classical form of manipulating information was used; it consisted of not separating pure information from an interpretation of the presented facts. Giving information together with its interpretation suggests that the interpreting content is an element of the information, and so it belongs to the objective category, free from ideological interpolations. In fact, it was precisely the opposite: when listening to a commentary prepared in this way the viewer assimilated the propaganda contents that the authorities wanted him to assimilate. Contrary to the expectations that a documentary will show events recorded on the film in an objective way, the PKF of the time being discussed was a tool in the propaganda war fought inside the country, so in this case there was no question of objectivism. It was substituted by a closely defined audio-visual message, in which the authorities' own interpretation of the world was created, and the aim was to impose this vision on the viewers.

Such constructions by the PKF defines its place inside the propaganda apparatus of the Polish People's Republic. It should be remembered here that propaganda is one of the forms of social communication combining information with persuasion, and in Polish reality after the war the persuasive function was decidedly at the foreground; and this function aimed to manipulate the behavior of the recipients of the propaganda message, that is, to influence their behavior, attitude, outlook on the world, and, ultimately, leading to the control of public opinion as exerted by the state authorities. ${ }^{13}$ The possibilities raised by the message and its expected results made propaganda one of the most important elements of the cold war. Its importance was additionally enhanced because in a totalitarian state (Poland at the end of the 1940s and the beginning of the 1950s was getting close to this model) a developed propaganda apparatus worked as hard as possible in order to indoctrinate society into believing in the state's official ideology. The authorities had broad experience in this field and efficient techniques were worked out that could be used in the new-old ${ }^{14}$ scope for activity. At the same time,

\footnotetext{
${ }^{13}$ DoBeK-OstrowskA, Bogusława. "Propaganda jako forma komunikowania [Propaganda as a Form of Communication]." In Beata OCIEPKA, Janina FrAS, and Bogusława DoBEK-OSTROwSKA. Teoria i praktyka propagandy [The Theory and Practice of Propaganda] (Wrocław: Wydawnictwo Uniwersytetu Wrocławskiego, 1999), 10.

${ }^{14}$ As was mentioned earlier, one of the main arenas of the Cold War conflict was its ideological aspect. The end of World War II coincided with the return to those aims that were set out by the leaders of the USSR before the outbreak of the war - "the export of the revolution," the expansion of the USSR and of Communism. Cf. Ernst Topitsch, Wojna Stalina. Dlugofalowa strategia radziecka wobec Zachodu jako racjonalna polityka sity [Stalins Krieg: Moskaus Griff
} 
it must be noted that the opposite side of the conflict also made progress on the propaganda field, for example taking action to keep up the morale of its citizens and to destroy in its opponent the will to fight in the struggles of World War II. ${ }^{15}$

In analyzing the propaganda message one must not forget about the two directions in which it may work: the external one, directed at the opponent and here the contents pointing at e.g. the superiority of the political system, social system, ideology or particular achievements of the side creating the message will be its essence - and the internal one, directed at the side's own citizens, imposing the desired interpretation of the causes, course and consequences of political-social phenomena, creating a way of perceiving reality or modeling behaviors and social attitudes in a way that is preferred by the author of the message. In the case of the subject being discussed it is important that in a totalitarian state special attention was paid to the propaganda message directed to people inside the country. It was exactly in this sphere that special possibilities of exerting influence were opened; and they were enhanced by the cooperation of all the channels of communication (giving each other credibility) that were managed from the center by means of a specialized propaganda apparatus. ${ }^{16}$ In the realities of the Cold War conflict, propaganda directed at the state's own citizens mobilized them to take action, created the feeling of a community based on a similar or, in fact, identical interpretation of the occurring phenomena and gave the possibility of rechanneling the frustration and aggression that were appearing. ${ }^{17}$

To those special features of the genre of the newsreel that make it suitable for propaganda communication, there should be added those assets that all audio-visual media have. First of all, they are attractive to the recipient, which not only results in a broad field of social impact but also guarantees the recipient's attention, and in this way makes the communicated contents easier to absorb. A film that affects the senses of sight and hearing, in addition to being shown in proper conditions limiting undesired stimuli (disrupt-

nach der Weltherrschaft], trans. Dariuzz Aleksandrowicz (Wrocław: Ossolineum, 1996), passim; MALENDOWSKi, Zimna wojna. Sprzeczności, konflikty i punkty kulminacyjne, 11-17.

${ }^{15}$ Marek HendryKowski, Film jako źródło historyczne [The Film As a Historical Source] (Poznań: Ars Nova, 2000) p. 11.

${ }^{16}$ Jarosław RABIŃSKI, "Władza nowoczesna? Rola mediów w państwie totalitarnym [Modern Authority? The Role of the Media in a Totalitarian State]." In (Kon)teksty kultury medialnej. Analizy i interpretacje [The (Con)Texts of Media Culture. Analyses and Interpretations], ed. Marek Sokołowski, vol. 2 (Olsztyn: Algraf, 2007), 8.

${ }^{17}$ Cf. Beata OCIEPKA, "Propaganda w Trzeciej Rzeszy [Propaganda in the Third Reich]," in DOBEK-OSTROWSKA, FRAS, OCIEPKA, Teoria i praktyka propagandy, 113. 
ing the perception), creates an illusion of participation in the presented events, engaging the recipient's emotions which, in turn, makes the recipient accept the presented contents more easily. ${ }^{18}$ Furthermore, presenting the newsreel at the beginning of the show was not without meaning, as the shows attracted viewers not necessarily interested in political or ideological contents. Owing to this, the field of propaganda influence was broadened, also comprising children and young people, that is, groups who, by nature, were more susceptible to manipulation.

The United States of America was present continuously in the PKF of the years 1948-1953, but its presence was marginal. This agrees with the special character of the PKF, in which Polish issues dominated, and most of its time devoted to other countries was designed primarily to present the USSR and the other countries of the Communist bloc. On the other hand, the USA were also referred to in materials that were not devoted directly to this superpower. The analyzed material also includes the film Go home. Wracaj do siebie of 1952 that was made by the authors of the PKF, and its takes and scenes were used in particular parts of the PKF.

\section{1. "THE WARMONGERS"19}

The image of the USA in the PKF directly resulted from the post-war position of the United States of America in the international arena, which was connected with such issues as the USA's leadership in the Western world, the directions of the policies conducted by this superpower, and its relations with capitalist and socialist countries. It should be said that generally the picture of international relations in the PKF is based on the true fact of the division of the world community into two opposite camps of countries that were concentrated around the Soviet Union on the one hand, and the United States of America on the other. However, the interpretation of the existing state follows from the consequence of our country belonging to the Communist camp: it is presented as a club of gentle peace lovers forced to defend itself by the USA's permanent actions aimed at unleashing another war in order to possibly greatly profit from it.

The term "warmongers" (which ultimately assumed the form of "American warmongers") that was repeated whenever an opportunity appeared

\footnotetext{
${ }^{18}$ RABIŃSKI, "Władza nowoczesna?," 10.

${ }^{19}$ USA, PKF 46/48
} 
served to strengthen that way of perceiving international relations ${ }^{20}$; the term had an unambiguously negative connotation - it described the nature of the enemy. The aim was to form in the viewer a stereotypical image of the world, in which the Manichean struggle between bad capitalist countries and the good countries of the people's democracy is fought. ${ }^{21}$

The United States of America, again in keeping with the actual situation, was presented as the leader of the bloc that was opposite to the Polish People's Republic and the other countries of the so-called people's democracy. However, this was accompanied by the suggestion that that leadership was exercised against the will of the citizens of Western Europe. In the opinion of the authors of the PKF, American supremacy deprived the countries that were members of the Western bloc of sovereignty, and their leaders were indeed traitors to their nations. ${ }^{22}$ In order to exercise control over their area of influence, Americans kept their armed forces in Western Europe. The situation was defined as an "occupation", an "invasion of Europe", a "Europe for the Americans". ${ }^{23}$ Americans showed no consideration for the people of Europe. In one of the films, the USA's leaders were charged with the intention to bring millions of Germans to their death by flooding villages and towns in the basin of the Rhine in order to build a strategic waterway. ${ }^{24}$ These tactics,

\footnotetext{
${ }^{20}$ For example Święto Armii Radzieckiej [The Anniversary of the Soviet Army], PKF 8/48; Karykatury Williama Groppera [William Gropper's Caricatures], PKF 48/49; W walce o pokój [In the Struggle For Peace], PKF 18/50; Bruksela [Brussels], PKF 32/50; Nowe przestepstwo podżegaczy [The Warmongers' New Crime], PKF 40/50; Podżegacze wojenni radza [The Warmongers' Debate], PKF 3/51; cf. Katarzyna MuRAwSKA-MuTHESIUS, “Jak rysować podżegaczy wojennych? Obraz Zachodu w socrealistycznej karykaturze radzieckiej i polskiej 1946-1954 [How to Draw Warmongers? The Picture of the West in Socialist Realist Soviet and Polish Caricature 1946-1954]," in Realizm Socjalistyczny w Polsce, 258-271 and the figures between pages 272 and 273.

${ }^{21}$ Janina FRAS, “Język propagandy politycznej [The Language of Political Propaganda]," in OCIEPKA, FrAS, and DOBEK-OSTROWSKA, Teoria i praktyka propagandy, 101; URBANIAK, "'Polska Kronika Filmowa,' 'zimna wojna" i świat', 228-230; Paweł NowaK, Swoi i obcy w językowym obrazie świata. Język publicystyki polskiej z pierwszej połowy lat pięćdziesiatych [Friends and Foes in the Language Picture of the World. The Language of Polish Journalism in the First Half of the Fifties] (Lublin: Wydawnictwo UMCS, 2002), 129-130, 140-142.

${ }^{22}$ Bruksela [Brussels], PKF 32/50; Dobrodziejstwa Planu Marshalla [The Benefits of the Marshall Plan], PKF 44/50; Podżegacze wojenni radza [The Warmongers' Debate], PKF 3/51; Przeciwko polityce wojny [The Warmongers' Debate; Against the Policy of War], PKF 18/51; Go home. Wracaj do siebie [Go home], PKF 1952. Cf. NowAK, Swoi i obcy w językowym obrazie świata, 86.

${ }^{23}$ Hamburg, PKF 32/50; W obronie pokoju [In Defense of Peace], PKF 49/51; Go home. Wracaj do siebie [Go home], , PKF 1952; Przeciwko układowi ogólnemu [Against the General Arrangement], PKF 23/52.

${ }^{24}$ Nowe przestęstwo podżegaczy [The Warmongers' New Crime], PKF 40/50.
} 
however, were noticed by ordinary people who organized themselves in huge protests on the streets of the biggest European cities to force the occupants to withdraw from the Old Continent or to give up their plans for the annihilation of the civilian population. ${ }^{25}$ Yet the Americans' influence on the Western countries was so strong that "obviously they will unanimously pass whatever Washington orders them to pass. They are already well-trained. Mr. Bevin, the liquidator of Great Britain's independence, Minister Schuman [...]. At Mr. Acheson's bidding they and the minor participants in the voting machine have passed the plan for the restoration of the neo-Hitlerian Wehrmacht...". ${ }^{26}$ This concerned not only Europe. The PKF viewer was persuaded that the USA would like to "change the UN into a branch of the United States' Department of State". ${ }^{27}$ This verbal communication was accompanied by an evocative picture, in which the well-dressed and self-satisfied political leaders of the Western countries were opposed by crowds of ordinary people joined by the common idea of frustrating the elites' dangerous scheming. The message reached the viewer about the rulers' fear of the working class that was growing in strength. Police forces were used to pacify it.

American policies were consistently defined as "imperialism": "Imperialists will not break our resistance. The Greek nation does not wish foreign intervention," 28 "I condemn the American imperialism that does not want peace in Korea...," "Bestialities of the American imperialism cannot be hidden". ${ }^{30}$ On the other hand, the broadening of the Soviet area of influence through revolutionary coups and the seizing of power by Communists are treated as a natural thing that does not have any imperialistic character. Soviet actions are presented as just counteractions forced by the enemy's attack. ${ }^{31}$ The political and military leaders of the USA weree also described by other pejorative epithets, as e.g. "craving wealth and blood, warmongers striving after World War III". ${ }^{32}$ The Western bloc is "the world of crime, evil and offence"33 and "the

\footnotetext{
${ }^{25}$ Go home. Wracaj do siebie [Go home], PKF 1952.

${ }^{26}$ Podżegacze wojenni radza [The Warmongers' Debate], PKF 3/51. Cf. MurawSKA-MuthESIUS, “Jak rysować podżegaczy wojennych?”, 259.

${ }^{27}$ Na sesji O.N.Z. [At the UN Session], PKF 43/50.

${ }^{28}$ Wiadomości z kraju [News from Poland], PKF 8/48.

${ }^{29}$ Hańba wrogom pokoju [Shame on the Enemies of Peace], PKF 29/53.

${ }^{30}$ Amerykański Oświęcim. Korea [The American Auschwitz. Korea], PKF 33/52.

${ }^{31}$ Święto Armii Radzieckiej. Konferencja ministrów w Pradze [The Anniversary of the Soviet Army. The Conference of Ministers in Prague], PKF 9/48; Hańba mordercom! [Shame on Murderers!], PKF 38/52.

32 Święto Armii Radzieckiej [The Anniversary of the Soviet Army] , PKF 9/48.

${ }^{33}$ Dzieciom bohaterskiej Korei [For the Children of the Heroic Korea], PKF 5/51.
} 
bloc of aggression and war" 34 (that is opposed by the socialist "world of peace, happy labor and brotherhood",35).

\section{2. "AMERICAN PERPETRATORS OF GENOCIDE"}

The Korean War that was fought in 1950-1953 got a lot of publicity in the PKF. A real armed conflict between the Communist and Capitalist worlds was used for complementing the metaphor of war that was hot in terms of propaganda, ${ }^{36}$ by connecting it with actual events. The course of this war, started by an attack by the Communist army of the Democratic People's Republic of Korea against the Republic of Korea, in the PKF was presented according to the one-sided interpretation of the conflict that was obligatory in Communist countries. According to this interpretation, the armed action conducted by the North Korean troops had the character of a national independence movement and aimed to liberate the Korean Peninsula from American occupation. Such fundamental information as the fact that the intervention in Korea was caused by the action of the Communist army from the North was not provided. The viewer was persuaded that the war was the effect of the "criminal assault launched by the American imperialists". ${ }^{37}$ The fact that the action by the United Nations was approved by a resolution of the UN Security Council and that, apart from Americans, soldiers of other NATO countries also took part in it was left unsaid. On the contrary, the action of the UN troops was presented as an exclusively American action for which only the United States of America was responsible. When explaining the source of the conflict the gestures of good will on the side of the Communist bloc were stressed, and at the same time the Americans' perfidiousness was underlined. In the opinion of the authors of the PKF, the US authorities broke their obligations and did not withdraw their troops from the southern part of the Korean Peninsula, although the USSR did so with respect to the northern areas. This was accompanied by the showing of the scene of the Korean people's cordial farewell to the withdrawing Soviet troops, treated as the "liberators of Korea from long-standing Japanese bondage". ${ }^{38}$

\footnotetext{
${ }^{34}$ Na sesji O.N.Z. [At the UN Session], PKF 43/50.

${ }^{35}$ Dzieciom bohaterskiej Korei [For the Children of the Heroic Korea], PKF 5/51; cf. URBANIAK, “"Polska Kronika Filmowa," 'zimna wojna' i świat ['The Polish News Reel,' the 'Cold War' and the World," 230-231.

${ }^{36}$ NowAK, Swoi i obcy w językowym obrazie świata, 125, 140-142.

${ }^{37}$ Hamburg, PKF $32 / 50$

${ }^{38}$ Korea, PKF 4/49.
} 
The communication concerning the Korean war was dominated by details intended to stress the brutality and ruthlessness of American soldiers. The courage and determination of the Koreans defending their homeland were contrasted with it. This juxtaposition sometimes assumes an indeed bizarre form, when the film shows smiling Koreans who are not upset by American bombardments and do their work in the ruined rice fields as if they were dancing. ${ }^{39}$ But usually the authors of the PKF focused on convincing the viewer about the cruelty and ruthlessness of the Americans, to this end using manipulation both in the footage and in the commentary. The US troops' actions are illustrated by scenes of falling bombs, burning buildings, ruined fields. Pictures of towns full of civilian population were juxtaposed with the effects of American bomb raids - photos of dead children or the deformed bodies of victims of air raids. The authors of the PKF stressed that American action was intentionally directed against civilians. Wounded children and crying mothers with babies were often shown. ${ }^{40}$

The commentary in the parts of the PKF devoted to the Korean War was extremely emotional and exceptionally crude: "MacArthur's brutish soldiers, beaten by the people's army and Chinese volunteers, vent their helpless fury on defenseless people ${ }^{41}$ "; "innocent victims of American bestiality"42, "American perpetrators of genocide". ${ }^{43}$ American soldiers are charged with using biological and chemical weapons, with the intentional bombardment of cultivated areas. Simply naming an action is not sufficient. The language of the commentary is laden with terms that are supposed to evoke the desired emotional reaction: "Who drops on Korean territory bombs with insects that are unknown in that country? Who has bred flies that are resistant to frost? Who has grafted typhoid, cholera, and bubonic plague germs onto them? [...] They are unable to defeat the fighting nation in an open struggle, so they have reached for the bacteriological weapon that has been condemned by mankind. [...] Those were American airplanes. It is they, the American perpetrators of genocide, who want to murder the whole Korean nation". ${ }^{44}$ The US authorities were charged with sabotaging the peace talks in Panmun-

\footnotetext{
${ }^{39}$ Dni i noce Korei [Korea's Days and Nights], PKF 1/52.

${ }^{40}$ K. Budoran, Propagandowy obraz polityki zagranicznej PRL w świetle polskiej Kroniki Filmowej z lat 1944-1956 [The Propaganda Image of the Polish People's Republic's Foreign Policy in the Light of Polish Newsreel of 1944-1956], 97 (typescript in the Author's collection).

${ }^{41}$ Dzieciom bohaterskiej Korei [For the Children of a Heroic Korea], PKF 5/51.

${ }^{42}$ Ibid.

${ }^{43}$ Amerykański Oświęcim. Korea [The American Auschwitz. Korea], PKF 33/52; Hańba mordercom! [Shame on the Murderers!], PKF 38/52.

${ }^{44}$ Hańba mordercom! [Shame on the Murderers!], PKF 38/52.
} 
jom that were to put an end to armed actions. According to the authors of the PKF, the Communist side was obviously the advocate of peace: "The delegation of Chinese volunteers and of the Korean army have been for months striving for an agreement and to put an end to the war. All the proposals made by the Korean-Chinese side are cynically torpedoed by the American delegation. The aggressors entered into negotiations under pressure by the public opinion of the whole world. Now they are making the negotiations impossible by their impudent demand to keep most prisoners of war". ${ }^{45}$

The bestiality of the American soldiers was to be contrasted to the humanitarian attitude of the Polish citizens who hurried - as far as was possible - to the aid of the Koreans affected by war. The PKF publicized an action for collecting gifts for Korean children that was organized by the Polish Committee for the Defense of Peace. It also did not fail to show the enthusiasm and joy of young Poles hurrying to the aid of their brotherly Communist society. To their gifts Polish children were supposed to "spontaneously" attach cordial letters to the "far away, and at the same time so close, children of heroic Korea", who must see that "apart from the dying world of crime, evil and offence, there is a powerful, ever stronger world of peace, happy work, heroism". Solidarity with Communist Korea fighting against American imperialism was bluntly expressed by the bombastic commentary: "We are with you, people of fighting Korea. We are with you against the warmongers and the sowers of the plague, against the criminals and perpetrators of genocide. The murderers must be punished! Peace will win! Peace must win!"” ${ }^{6}$

\section{3. "THE NEW SS" 47}

Comparing the way in which Americans acted to the Hitlerian methods was a characteristic propaganda measure directed against the USA, and it was clearly seen especially when analyzing fragments of the PKF devoted to the Korean War. This was an especially weighty propaganda argument as it affected emotions at the time when the memory of the occupation years was still vivid among Poles. The parallel of Americans $=$ Hitlerites occurs very often in the PKF's materials in the context of the Korean War. One of the films of 1952 is indeed titled "The American Auschwitz". It shows one of

\footnotetext{
${ }^{45}$ Amerykański Oświęcim. Korea [The American Auschwitz. Korea], PKF 33/52; cf. BudORAN, Propagandowy obraz polityki zagranicznej PRL, 106.

46 Ibid.

4747 Amerykański Oświęcim. Korea [The American Auschwitz. Korea], PKF 33/52.
} 
the camps for Korean prisoners of war captured by Americans. The photos present a column of unarmed men wearing uniforms, escorted by fullyequipped American soldiers. And the commentary goes: "After a new massacre - selection according to the Nazi method. In gas masks and with machine guns against defenseless prisoners. [...] The whole world was shaken by the crimes of the new SS. The executioners from the American Auschwitz will not escape punishment". "The message is very clear: the Americans are using the same methods that the SS units had earlier used. Reference to historical experiences sounds menacing: punishment is inevitable, like the punishment that was inflicted on the German leaders. It is worth paying attention here to the generalization (the use of the propaganda rule of "universality") achieved by such phrases as "all the world was shaken...,"49 "nations know...," "the nation replies...," "51 "the progressive opinion of the whole world has adequately assessed...,"52 "the followers of democracy in the whole world are joined...," evident nature of the presented point of view by suggesting that the opponents of the propagated thesis constitute a minority and are resorting to devising plots in order to achieve their intended aims that are contrary to the expectations of the overwhelming majority of the world community.

Let us add that the use of the means aimed at making Americans and Nazis equal were also seen in other parts of the PKF, not necessarily connected with the Korean War. In the film Go home. Wracaj do siebie an image of Paris was shown where the streets are teeming with American soldiers. A close-up of a board follows, where there is information, in English at the top, and below in French: "In Paris which - as is well-known - is the capital of France, the French language is in second place after English. We remember what it was like in our country under the SS occupation". ${ }^{54}$ The voiceover informed the viewers that General Dwight Eisenhower "until recently had his office in the Victoria hotel that earlier had been the main seat of the Nazis, and today is the headquarters of the «Atlanteans»". ${ }^{55}$ Harry S. Tru-

\footnotetext{
${ }^{48}$ Ibid.

${ }^{49} \mathrm{Ibid}$.

${ }^{50}$ Go home. Wracaj do siebie [Go home], PKF 1952.

${ }^{51}$ Bez nas [Without Us], PKF 25/50.

${ }^{52}$ Walka ze stonka [The Struggle Against the Colorado Beetle], PKF 25/50.

${ }^{53}$ USA, PKF 9/49.

${ }^{54}$ Go home. Wracaj do siebie [Go home], PKF 1952.

${ }^{55}$ Ibid. The negative picture of Eisenhower in the PKF of the 1950 s was in contrast to the positive image of this military officer and politician from the first years after the war - BUDORAN, Propagandowy obraz polityki zagranicznej PRL, 101, 107.
} 
man's and the leader of the Third Reich Adolf Hitler's statements about Divine Providence entrusting their nations with a mission were also compared.

Statements made by American politicians were quoted that, in the opinion of the authors of the PKF, were to prove their conviction about the racial superiority of US citizens over Europeans: "The American Senator Beveridge said «God ordered our American race to civilize the world». According to American scholars an American is the most developed kind of man". ${ }^{56}$ This was an obvious suggestion that in the USA the racist theories developed by the ideologists of the Third Reich were being continued, and this time they aimed to harm the inhabitants of Europe. Here, it should be noted that in social relations in the USA there were quite a lot of examples of racist behavior. However, they were primarily directed against black people. There are no serious data that would confirm the suggestions offered by the PKF. What we are dealing with here is the transfer or interpolation of conclusions from facts concerning a small fragment of social life into other spheres of interpersonal relations.

One of the most serious charges against the US authorities was the intention to restore the military power of Germany. The conviction that the German army was a "neo-Nazi" "new Wehrmacht" commanded by Nazi generals was instilled in the recipient, corresponding with the continuous comparisons between Americans and Nazis that was described above. The suggestion that Americans were striving to rebuild the Nazi military power was clear: "General Keitel has not lived to see this moment. But others have Gen. Manteuffel, Gen. Guderian - the Americans remind him of his march to Moscow. The Americans order him to forget how he escaped from there. The pathetic strategists of the Ardennes have a short memory. But nations do remember mothers hugging their babies when Western culture was saved by the Nazis. [...] Nations can see how Western culture is today being saved by the murderers of Korean children". ${ }^{57}$ These epithets were accompanied by an evocative picture consisting of, alternately, Nazi and American soldiers and politicians whose behavior, brutality, smiles and self-confidence were contrasted with ordinary people's pain, despair, wounds, poverty and terror.

Finally, it has to be noted that some sins ascribed to the Americans may make one laugh today (it is not by accident that some fragments of the PKF were included in books of the type "The Funniest Polish Newsreels"). An

\footnotetext{
${ }^{56}$ Go home. Wracaj do siebie [Go home], PKF 1952.

${ }^{57}$ Ibid. Cf. ...a w Niemczech Zachodnich [...and in West Germany], PKF 41/51; W obronie pokoju [In Defence of Peace], PKF 49/51; O Zjednoczone Niemcy [For a United Germany], PKF $4 / 53$.
} 
example of such charges was blaming the Americans for the appearance in Poland (and in other Socialist countries) of the Colorado beetle. Strong words were said: "The progressive opinion of the whole world adequately assessed the American airmen's crimes; they dropped large quantities of Colorado beetles onto the fields in the German Democratic Republic [...] The American beetle will not succeed either in Poland or in Germany. The warmongers' plan will misfire". ${ }^{8}$

It is worth paying attention here to the characteristic military language used in the PKF's commentary. It has a double function. Firstly, it made the viewer treat every manifestation of American presence (even in the form of the "imperialist" insect) in terms of a struggle, at the same time enhancing the vigilance against the opponent. Secondly, it implied a dynamism with which Polish society resisted the American threat, at the same time contributing to the Poles' mobilization around the Communist authorities that were the leaders of the fight. ${ }^{59}$ And in this way, the appearance of the Colorado beetle was indeed shown as the initial phase of an armed attack. It was dropped by airmen - so it is a kind of air-landing by the enemy forces. On the Polish seashore lines of volunteers are moving, having the task of finding and destroying the enemy. ${ }^{60}$ As the above example shows, in practice the requirements of propaganda did not leave any possibilities of excluding any issues from being perceived from the perspective of the Cold War. Even the appearance of a pest was ascribed to it and this fact was used as an opportunity to criticize the United States of America.

\section{4. "THE BONDAGE OF THE DOLLAR",61}

Economic issues had a lot less space than political ones in the PKF materials of the time discussed. As a rule, it was also subordinate to the latter, being used to complement the arguments presenting the USA in a decidedly negative light. In accordance with the propaganda vision of reality, the political and military aspects of American rule over Europe and the world were supplemented with the economic tools of exerting influence on the countries that were subordinate to the USA. Using the economic weapon in a world that was ruined by the war was proof of the Americans' ruthlessness in their

\footnotetext{
${ }^{58}$ Walka ze stonka [The Struggle Against the Colorado Beetle], PKF 25/50.

${ }^{59}$ Cf. NowaK, Swoi i obcy w językowym obrazie świata, 95-107.

${ }^{60}$ Walka ze stonka [The Struggle Against the Colorado Beetle], PKF 25/50.

${ }^{61}$ Francja [France], PKF 4/48.
} 
efforts to dominate it. Such a conviction was to be formed by frequently referring to the emotions in showing economic issues. A special edition of the PKF from 1950 entitled We, who have signed underneath is an example of this strategy.

The leading motif of the film is the campaign for Poles' mass signing the appeal for peace; the appeal demanded the introduction of a ban on the use of nuclear weapons. In the commentary appalling information appears: "60 bankers from the USA earned 57 billion dollars from the Second World War" ${ }^{62}$ The way economic issues are presented in the PKF is inscribed in the logic of the black-and-white propaganda message that was analyzed above. In material of this type only the wording is different: "warmongers" are substituted in the role of the ruling center by "Wall Street" "managing the Fascist plot". ${ }^{63}$ On the other hand there is no space for positive, or at least neutral, contents. The author of the present work was only able to find one fragment of the PKF from the first year of the period discussed where economic issues in the context of Polish-American relations were presented in a neutral (which should be understood as 'positive') light; it was when information was given that the Polish authorities had bought 30 of the most modern railway engines from the USA. ${ }^{64}$

In the PKF authors' perspective, the Western world was plunged into an economic crisis (in contrast to the Soviet Union and the other countries of the people's democracy, where a steady increase in the standard of living was taking place). In order to prevent the deepening of the crisis, the owners of American companies acted according to the principle "rather war than a crisis". ${ }^{65}$ The viewer was being persuaded that such a strategy was one of the basic causes of the USA's actions in the international arena. It was suggested that the proverbial "companies' and concerns' owners" were the real decision-makers, in the sphere of foreign policy as well. As in the case of the presentation of political issues, the protests by communities and nations directed against the American attempts to shift the costs of conducting imperialist policies to ordinary people were shown. The actions of collecting donations for "dollar helmets" 66 will fail. Approvingly, masses of workers were

\footnotetext{
${ }^{62}$ My niżej podpisani [We, who have signed underneath], PKF 1950, quoted after: CIEŚLIŃSKI, Piękniej niż w życiu, 24.

${ }^{63}$ Francja [France], PKF 4/48; USA, PKF 9/49. Cf. NowAK, Swoi i obcy w językowym obrazie świata, 74.

${ }^{64}$ Wiadomości z kraju [News From Poland], PKF 8/48..

${ }^{65}$ Go home. Wracaj do siebie [Go home], PKF 1952.

${ }^{66}$ Bez nas [Without Us], PKF 25, 50.
} 
presented who used strikes in the economic (and political) struggle against the Americans ${ }^{67}$ : "The working class fights for the liberation of France from the yoke of the American imperialism", it does not agree "to be a market for the American capital". ${ }^{68}$

The authors of the PKF noted that the USA were an economic power using its privileged position to conduct imperialist policies - those of subordinating new territories. The Marshall Plan was to serve this aim, in their opinion: "They said that they crossed the ocean in order to help the harried nations of West Europe to regain happiness. They said that they came to their aid. The good uncle from America started sending parcels: milk powder, canned food, Coca-Cola. A new era started. With American help life will be beautiful". ${ }^{69}$

In carrying out the propaganda tasks, the PKF authors, however, unmasked the Americans" "real" aims: "But soon an awakening came. In daylight, reality appeared. [...] Who not very long ago promised liberation from poverty, from the fear of unemployment? With American help factories were closed, pay was ever smaller, prices ever higher, there were more and more unemployed people". ${ }^{70}$ So the message was created that the USA's economic expansion was the real aim of American aid; and this manifested itself in a variety of branches of industry and services through looking for new markets and leading to the driving away of local entrepreneurs from European business. ${ }^{71}$ Hence, it was to be a complementary way of putting modern imperialism into effect; in it, the whole of Europe was an area to be taken over, and treacherous American colonialism assumes the form of false aid leading, indeed, to the "bondage of the dollar". ${ }^{72}$ The footage showed contrasting pictures: one of replete, smiling American soldiers in Paris; French women accompanying them, wearing expensive furs; a villa in the suburbs of Paris where Mr. and Mrs. Eisenhower resided - and the other of the streets of Paris in the morning, full of poor, homeless, unemployed tramps. The picture and commentary suggested a rift between the official American propaganda talking about economic support for the countries of Western Europe, and the reality, in which the aid is designed for narrow social elites, leaving the low-

\footnotetext{
${ }^{67}$ Przeciwko polityce wojny [Against the Policy of War].

${ }^{68}$ Francja [France], PKF 4/48.

${ }^{69}$ Go home. Wracaj do siebie [Go home], PKF 1952.

${ }^{70}$ Ibid.

${ }^{71}$ Ibid; Francja [France], PKF 4/48; ; Dobrodziejstwa Planu Marshalla [The Benefits of the Marshall Plan], PKF 44/50.

${ }^{72}$ Francja [France], PKF 4/48.
} 
er layers of society alone to their own devices or, indeed, worsening their economic situation on purpose. On the other hand, the Americans themselves profit from the boom in the economy and from the rising dollar; they come to Europe in crowds in order to make a profit from the purchasing power of their currency. A reporter for the PKF showed this tendency when presenting the carnival festivities in Nice: "[...] the franc is falling dramatically, and the dollar is rising. And in Nice it is the height of the carnival. Carefree crowds are enjoying themselves, forgetting about the hard times. This is not strange. Most of the people are American tourists who are pleasantly surprised by the rise of the dollar. As it turns out, while the times are hard for France they are the best guardians of the joyful tradition of Nice". ${ }^{73}$

The authors of the PKF persuaded the viewer that Americans are insensitive to the plight of the ordinary man. The fate of the individual has been subordinated to the demands of "the great politics", in the name of which Americans did not hesitate to displace the population of whole German villages in order to make their strategic investments in that area. With the use of arranged takes in which close-ups of the faces of despairing villagers often appeared, a message about the ruthlessness of the new colonizers was transmitted. Mass relocations combined with a loss of people's homes and most of their belongings was the effect of the colonizers' actions. ${ }^{74}$

\section{5. "SAVAGERY, SADISM, PORNOGRAPHY",75}

The question of the internal affairs of the United States of America remained in the background of the political, military and economic issues connected with the USA. In the sphere of interest of the authors of the PKF the problems found especially in the social-economical situation of the US population, the American way of life and American morality. As in the case of the contents concerning political or economical reality that were analyzed above, there is no use looking for a detailed, many-sided view of American internal affairs. A schematic, one-sided media communication was present that was exclusively subordinate to the principles of propaganda. Only at the beginning of the period discussed did individual examples of the neutral treatment of American subjects appear: a documentary on the expedition of

\footnotetext{
${ }^{73}$ Ibid.

${ }^{74}$ Po wizycie Eisenhowera [After Eisenhower's Visit], PKF 9/51.

${ }^{75}$ Oto Ameryka [This Is America], PKF 3/53.
} 
American wild animal hunters ${ }^{76}$ or coverage of the celebration of Easter on the East and West Coast of the USA. ${ }^{77}$ In the next clips from the PKF, the United States of America was only a place that was plagued by all kinds of evil, crime and licentiousness. In this context, special attention should be paid to the film Oto Ameryka (This Is America) from 1953 which is a documentary about the Warsaw exhibition with the same title.

The PKF authors (like the authors of the exhibition) exposed exclusively negative examples of American life. In their opinion, the USA was a country where freedom was only a meaningless slogan, a country of intolerance where the multimillion Negro population was deprived of the protection of law. They juxtaposed the official American attributes with the real - in their opinion - situation in the USA. So the New York Statue of Liberty cast a shadow in the shape of a policeman with a club raised to strike. A take showing a dark-skinned man hiding his face in his hands was commented on in the following manner: "What is awaiting this citizen of the free country? The specter of the Ku-Klux-Klan. A noose round his neck tightened by American fascists". ${ }^{78}$ Based on the real fact of the discrimination against the Negro population, invalid generalizations and simplifications were made: "There is freedom in that country for mob law and lynching. There is freedom in that country for factory owners and strike-breakers. The state and police defend to the end the freedom of trusts and concerns, the right to exploit". ${ }^{79}$ The conclusion was simple: freedom is a notion that is eagerly referred to by American politicians, but it is an empty platitude, the elites' privilege, while the masses are kept in constant fear by the police that aree guarding the American social bondage. ${ }^{80}$ On the strength of international contracts to receive footage from film studios in Western countries, the PKF authors used them to illustrate their thesis about American intolerance towards those who criticized the realities there: members of the Communist party, ${ }^{81}$ actors ${ }^{82}$ leftist intellectuals. ${ }^{83}$ When calling those practices fascist they did not notice that the people taking part in the protests in the USA and in the countries of Western Europe could express their views freely; they also did not see the open attitude of the US authorities to foreign guests or the

\footnotetext{
${ }^{76}$ USA, PKF 4/48.

${ }^{77}$ Wielkanoc 1948 [Easter 1948], PKF 13/48.

${ }^{78}$ Oto Ameryka [This Is America], PKF $3 / 53$.

${ }^{79}$ Ibid.

${ }^{80}$ Cf. USA, PKF 9/48; USA, PKF 15/49.

${ }^{81}$ USA, PKF 9/48.

${ }^{82}$ Chaplin w Europie [Chaplin in Europe], PKF 49/52.

${ }^{83}$ USA, PKF 15/49.
} 
American freedom of speech. Consistently, but also bizarrely, the commentary said: "Despite the Department of State's attempts to torpedo the Congress [of American Intellectuals in Defense of Peace - J.R.] its sessions got a lot of publicity. The American authorities, irritated by this fact, ordered the foreign delegates to leave the country immediately after the Congress ended". ${ }^{84}$

An interesting propaganda measure was using labels, classifying American politicians according to their being situated either in the "Rooseveltian" peace camp or in the Republican circles after the war. The clearest case of the use of this measure was in 1948, when the Republican Thomas Dewey was defined as "Wall Street's darling" 85 and an "advocate of the Third Reich," ${ }^{86}$ and - which is interesting - hopes were pinned on the re-election of Harry Truman who announced his directing his policies towards peace, which the PKF authors described as putting Roosevelt's idea into effect. ${ }^{87}$ It is worth noting that the optimism about Truman did not issue from past experiences but was an expression of the necessity to recognize the results of the presidential election in the USA, and derived from the fact that Roosevelt and Truman were both members of the Democratic Party. At the same time, for the use of propaganda, the figure of Roosevelt was "appropriated" by them, ignoring the change in his attitude towards the Communist world in the last weeks of his life.

On the other hand, Henry Wallace was presented as an equal candidate in the presidential election campaign; he was the co-founder of the Progressive Party and even though he only won a little over 1.1 million votes (over twenty times less than Truman), in the campaign he warned the US citizens against the "warmongers' underhand scheming ${ }^{88}$ ", calling for a return to Roosevelt's social-political principles. The figure of another politician from the Progressive Party, the graphic artist William Gropper, was also shown approvingly by the PKF; with his caricatures (also printed in Polish satirical periodicals) he "unmasks the Anglo-Saxon imperialists, American bankers and death-manufacturers, the authors of the Marshall Plan and of the Atlantic bloc". ${ }^{89}$ The whole of the propaganda message was complemented by photos of Gropper's works where the author, in a way typical of the post-war

\footnotetext{
${ }^{84}$ Ibid.

${ }^{85}$ USA, PKF 46/48.

${ }^{86}$ Ibid.

${ }^{87}$ Ibid.

${ }^{88}$ Ibid.

${ }^{89}$ Karykatury Williama Groppera [William Gropper's Caricatures], PKF 48/49; cf. BuDORAN, Propagandowy obraz polityki zagranicznej PRL, 108.
} 
years, showed, among others, members of the US political and financial elites as fat pigs, or stressed their Semitic features, all with the omnipresent symbols of the American currency. ${ }^{90}$

In the PKF footage references may also be found to Americans' morality. The corruption of morals in the USA is stressed, first of all by criticizing the protests for sexual liberty. As examples, the PKF showed the covers of pornographic magazines and the pages of comic books designated for young readers that contained elements of pornography or clothes with imprints of female nudes. The commentary was equally blunt: "Painting - naked sluts on flashy neckties and on colorful pants. Literature - savagery, sadism, pornography. Seven deadly sins for one dollar. Future gangsters must be brought up from their earliest years. They will be needed in Korea. They will be needed in Europe". ${ }^{91}$ As a typical example of "American life" fragments of westerns were presented that were full of killing. Americans' drunkenness was also emphasized. ${ }^{92}$

\section{CONCLUSION}

The analysis of the contents of clips of Polish Newsreel from the years 1948-1953 concerning the United States of America in political, international, military, economic and moral aspects points to the subordination of the truth to the demands of the propaganda message. The PKF authors did not inform their viewers about real facts. The image of the USA was inscribed in the vision of the world that they had created, a vision in which the States take the place of the "empire of evil", the leader of a world of darkness, directed by its own political and economic interest only, ruthlessly subordinating the countries of Western Europe. The US leaders continue the criminal actions of Nazi Germany using the same methods, and even the same people - war criminals. They do not hesitate to kill innocent people and destroy their homes and fields in order to achieve their aims. The American economy is one of the most important tools of this imperialist policy; it leads to the economic dependence of Western European countries. Moreover, the US elites propagate "the American way of life" based on the corruption of morals and a predilection for using violence. In this schematic, black-and-white,

\footnotetext{
${ }^{90}$ Karykatury Williama Groppera [William Gropper's Caricatures], PKF 48/49; cf. Karykatura rumuńska [The Rumanian Caricature], PKF 38/50; MURAWSKA-MuTHESIUS, "Jak rysować podżegaczy wojennych?”, 263-269.

${ }^{91}$ Oto Ameryka [This Is America], PKF $3 / 53$.

${ }^{92}$ Go home. Wracaj do siebie [Go home], PKF 1952.
} 
world anything that is connected with the USA is evil, dirty and to be condemned.

The propaganda apparatus, to which Polish Newsreel was subordinate, used a rich variety of propaganda rules and techniques in creating the image of the United States of America, including those as efficient as the selection of the footage presented - passing partly or completely over some facts, excessive generalizations, false interpretations, repetitions of characteristic clusters of ideas and not separating the information and interpretation layers.

It should be stressed that in order to achieve the set aims a modern medium was used, which in this case was film. Combining picture, sound and commentary on the one hand and the particular physical conditions met during the screening of the newsreel on the other, afforded the possibility of the viewer deeply experiencing the scenes that were offered and his emotional involvement in them, and as a consequence all of this resulted in the viewer's identification with the imposed interpretation of the viewed footage.

An important role was also played by music which constituted part of the soundtrack of the film. When presenting scenes concerning the United States of America it usually assumed a sombre form, full of discord and the staccato effect in order to illustrate the cruelties committed by the Americans - or, on the contrary, it was contrasted with the picture, giving the fragment edited in this way a cynical overtone.

These propaganda actions and the propaganda war were one of the most important aspects of the Cold War. Modern analysis of historical sources, which the newsreel is, has to take this aspect into consideration. This will make it possible to interpret it correctly and to understand the complexities of the conflict that lasted for several dozen years and also had an effect on the post-war history of Poland.

\section{BIBLIOGRAPHY}

\section{SOURCES}

Polska Kronika Filmowa [Polish Newsreel] 1948: Nos. 4, 8, 9, 13, 46.

Polska Kronika Filmowa [Polish Newsreel] 1949: Nos. 4, 9, 15, 48.

Polska Kronika Filmowa [Polish Newsreel] 1949: Nos. 4, 9, 15, 48.

Polska Kronika Filmowa [Polish Newsreel] 1950: Nos. 18, 25, 32, 38, 40, 43, 44;

Polska Kronika Filmowa [Polish Newsreel] 1951: Nos. 3, 5, 9, 11, 18, 41, 49.

Polska Kronika Filmowa [Polish Newsreel] 1952: Nos. 1, 23, 33, 38, 49.

Go home. Wracaj do siebie [Go home], 1952.

Polska Kronika Filmowa [Polish Newsreel] 1953: Nos. 3, 4, 29. 


\section{STUDIES}

BUdORAn, K. Propagandowy obraz polityki zagranicznej PRL w świetle polskiej Kroniki Filmowej z lat 1944-1956 [The Propaganda Image of the Polish People's Republic's Foreign Policy in the Light of the Polish Newsreel of 1944-1956] (typescript in the Author's collection).

CieŚlıŃSKI, Marek. Piękniej niż w życiu. Polska Kronika Filmowa 1944-1994 [More Beautiful Than Life: Polish Newsreel 1944-1994]. Warszawa: Trio, 2006.

CIEŚLIŃSKI, Marek. "Polska Kronika Filmowa 1945-1955. W kleszczach urzędniczych decyzji [Polish Newsreel 1945-1955: In the Grip of the Clerks' Decisions].” In Realizm socjalistyczny $w$ Polsce z perspektywy 50 lat [Socialist Realism in Poland from the Perspective of 50 Years], edited by Stefan Zabierowski, 244-257. Katowice: Wydawnictwo UŚ, 2001.

Dobek-Ostrowska, Bogusława. "Propaganda jako forma komunikowania [Propaganda as a Form of Communication].” In Beata OCIEPKA, Janina FrAS, and Bogusława DoBEK-OSTROwSKA. Teoria i praktyka propagandy [The Theory and Practice of Propaganda], 7-28. Wrocław: Wydawnictwo Uniwersytetu Wrocławskiego, 1999.

FRAS, Janina. "Język propagandy politycznej [The Language of Political Propaganda]." In Beata OCIEPKA, Janina FrAS, and Bogusława DOBEK-OSTROwSKA. Teoria i praktyka propagandy [The Theory and Practice of Propaganda], 84-110. Wrocław: Wydawnictwo Uniwersytetu Wrocławskiego, 1999.

HENDRYKOWSKI, Marek. Film jako źródło historyczne [The Film As a Historical Source]. Poznań: Ars Nova, 2000.

HiRszowicz, Maria. Pułapki zaangażowania. Intelektualiści w stużbie komunizmu [The Traps of Involvement: Intellectuals in the Service of Communism]. Warszawa: Scholar, 2001.

KARCZOWA, Helena. "Reportaż filmowy i kronika jako źródło historyczne [The Film Documentary and the Newsreel as a Historical Source]." Studia Źródtoznawcze 16 (1971): 25-31.

Lemann-ZAJIČEK, Jolanta. Kino i polityka. Polski film dokumentalny 1945-1949 [The Cinema and Politics: Polish Documentary Films 1945-1949]. Łódź: PWSFTviT, 2003.

MadeJ, Alina. Kino. Władza. Publiczność. Kinematografia polska w latach 1944-1949 [The Cinema. The Authorities. The Audience: Polish Cinematography in the Years 1944-1949]. Bielsko-Biała: Prasa Beskidzka, 2002.

MALENDOWSKI, Włodzimierz. "Zimna wojna. Rywalizacja radziecko-amerykańska w systemie bipolarnym. Problemy periodyzacji i rekonstrukcji najważniejszych zdarzeń [The Cold War. The Soviet-American Rivalry in a Bi-polar System: The Problems of the Periodization and Reconstruction of the Most Important Events]. In Zimna wojna (1946-1989) i jej konsekwencje dla ładu międzynarodowego [The Cold War (1946-1989) and Its Consequences For the International Order], edited by Bogdan Koszel and Sebastian Wojciechowski, 9-35. Poznań: Instytut Zachodni. Wyższa Szkoła Nauk Humanistycznych i Dziennikarstwa 2007.

MALENDOWSKI, Włodzimierz. Zimna wojna. Sprzeczności, konflikty i punkty kulminacyjne w radziecko-amerykańskiej rywalizacji [The Cold War. The Contradictions: Conflicts and Culminating Points in the Soviet-American Rivalry]. Poznań: Wydawnictwo Naukowe Instytutu Nauk Politycznych i Dziennikarstwa UAM, 1994.

MuRAwSKA-Muthesius, Katarzyn. "Jak rysować podżegaczy wojennych? Obraz Zachodu w socrealistycznej karykaturze radzieckiej i polskiej 1946-1954 [How to Draw the Warmongers? The Picture of the West in the Socialist Realist Soviet and Polish Caricature 19461954]." In Realizm socjalistyczny w Polsce z perspektywy 50 lat [Socialist Realism in Poland from the Perspective of 50 Years], edited by Stefan Zabierowski, 258-272. Katowice: Wydawnictwo UŚ 2001. 
NowaK, Paweł. Swoi i obcy w językowym obrazie świata. Język publicystyki polskiej z pierwszej polowy lat piećdziesiatych [Friends and Foes in the Language Picture of the World: The Language of Polish Journalism in the First Half of the Fifties]. Lublin: Wydawnictwo UMCS, 2002.

OCIEPKA, Beata. "Propaganda w Trzeciej Rzeszy [Propaganda in the Third Reich]." In Beata OCIEPKA, Janina FrAS, and Bogusława DOBEK-OSTROWSKA. Teoria i praktyka propagandy [The Theory and Practice of Propaganda], 113-130. Wrocław: Wydawnictwo Uniwersytetu Wrocławskiego, 1999.

RABIŃSKI, Jarosław. "Władza nowoczesna? Rola mediów w państwie totalitarnym [Modern Authority? The Role of the Media in a Totalitarian State].” In (Kon)teksty kultury medialnej. Analizy i interpretacje [The (Con)Texts of Media Culture. Analyses and Interpretations], edited by Marek Sokołowski. Vol. 2, 7-15, Olsztyn: Algraf 2007.

SzCZUROwSKI, Maci9ej. "Dokument filmowy i telewizyjny. Określenie problematyki badawczej, [Film and TV Documentaries: Defining the Research Issues]." In Dokument filmowy i telewizyjny [Film and TV Documentaries], edited by Maciej Szczurowski, 21-37. Toruń: Wydawnictwo Adam Marszałek 2004.

TOPITSCH, Ernst. Wojna Stalina. Dlugofalowa strategia radziecka wobec Zachodu jako racjonalna polityka sity [Stalins Krieg: Moskaus Griff nach der Weltherrschaft]. Translated by Darisuz Aleksandrowicz. Wrocław: Ossolineum, 1996.

URBANIAK, Janusz. "O sposobie realizowania 'Polskiej Kroniki Filmowej' w latach czterdziestych [On the Way 'Polish Newsreel' Was Edited in the Nineteen-Forties]." In Estetyka i struktura dzieła filmowego [The Esthetics and Structure of the Film], edited by Jan Trzynadlowski, 203-213. Wrocław: Wydawnictwo Uniwersytetu Wrocławskiego, 1987.

URbaniaK, Janusz. “'Polska Kronika Filmowa,' 'zimna wojna' i świat. O zmienności ekranowego obrazu ['Polish Newsreel,' the Cold War and the World: On the Changeability of the Screen Picture]," In Film: obraz - język - wyobraźnia - idea [Film: Picture - Language - Imagination - Idea], edited by Jan Trzynadlowski, 213-231. Wrocław: Wydawnictwo Uniwersytetu Wrocławskiego, 1994.

\section{THE IMAGE OF THE UNITED STATES OF AMERICA IN THE POLISH NEWSREEL (PKF) 1948-1953}

\section{S u m m a ry}

This article analyzes the contents of sections of Polish Newsreel (PKF) of the years 19481953 concerning the United States of America in the context of political, international, military, economic and social issues. The image of the USA shown in Polish Newsreel did not have a lot in common with reality and it was part of the vision of the world created for propaganda needs. The propaganda machine, a part of which Polish Newsreel was, in order to achieve the aims that it had set out, used a whole palette of propaganda techniques and rules: selecting the prepared footage, generalizations, the use of characteristic clusters of ideas ("warmongers", "American perpetrators of genocide", "the new SS", "the bondage of the dollar"), combining information with interpretation. All of this was done with the use of the modern medium, that is, film. Joining the layers of pictures, sound and commentary, as well as the particular conditions encountered during screenings of Polish Newsreel shows gave the viewer the possibility to deeply experience the scenes presented, to get emotionally involved in them, and, hence, to identify with the imposed interpretation of the viewed material.

Key words: Polish Newsreel; PKF; propaganda; United States of America; Cold War; Polish People's Republic. 
Translated from Polish by Tadeusz Karlowicz

The preparation of the English version of Roczniki Humanistyczne and its publication in electronic databases was financed under contract no. 836/P-DUN/2018 from the resources of the Minister of Science and Higher Education for the popularization of science. 